\title{
Groundwater Development for Dry Season Irrigation in North East Ghana: The Place of Local Knowledge
}

\author{
Lydia Kwoyiga * and Catalin Stefan $(\mathbb{D}$ \\ Department of Hydrosciences, TU Dresden, 01069 Dresden, Germany; catalin.stefan@tu-dresden.de \\ * Correspondence: lydia.kwoyiga@tu-dresden.de; Tel.: +49-151-6392-3435
}

Received: 10 September 2018; Accepted: 22 November 2018; Published: 25 November 2018

\begin{abstract}
The use of groundwater resources for dry season irrigation has gained currency in Ghana. The north-east of the country has seen the cultivation of vegetables using groundwater from shallow aquifers; an emerging livelihood activity which lessens food insecurity and stems the tide of rural-urban migration. This practice in northern Ghana is deeply rooted in local knowledge. Using the Atankwidi catchment, this paper examines the role of local knowledge in understanding and exploiting groundwater for irrigation. A qualitative approach was used which allowed for in-depth catchment-level investigations, using group discussions, key informant interviews and informal discussions with irrigators, traditional leaders, earth priests, men, and women. Evidence from analysis revealed that local knowledge enabled farmers to locate groundwater points and determine the source and timing of groundwater recharge. Traditional communities are also able to identify the period for constructing wells. In addition, local knowledge enabled farmers to adopt strategies of conjunctively using groundwater with alternative water to cope with insufficient groundwater resources. We argue that local knowledge serves as a useful tool in sustaining dry season irrigation despite the challenges of a lack of government support and threats of global change.
\end{abstract}

Keywords: groundwater; irrigation; local knowledge; wells; Ghana; dry season; adapt; development; catchment; qualitative

\section{Introduction}

As a way of securing water for any human activity including irrigation, groundwater development has been taking place since medieval times. The Quanat system, a Persian technique developed about 3000 years ago which enabled groundwater in alluvial fans to be tapped and transported to the earth surface for use [1], is a typical example. In modern times, countries such as the United States, India, and nations in Latin America have made great efforts to develop groundwater for irrigation. These strides have been well documented and replicated elsewhere. However, in developing countries such as Ghana, the situation is different and thus the focus of this article.

According to Foster et al. [2], groundwater development for activities such as irrigation in Sub Saharan Africa has received less investment. In Ghana, since after independence, the focus of government on irrigation has been to promote formal irrigation through the development of surface water resources. Groundwater irrigation has not been given due attention [3].

Namara et al. [4] revealed that the general notion is often to develop groundwater for domestic purposes in the country. This is seen in the words of Barry et al. [5] who admitted that it is groundwater for domestic purposes which is appreciated and receives substantial funding from various sources. According to Chokkakula and Giordano [6] (p. 794), "though the WRC is the nodal agency for managing water resources in the country, its role is largely regulatory. The other irrigation development agency, GIDA, has a primary focus on surface water irrigation development". They further revealed 
that interactions with the Ghana Irrigation Development Authority (GIDA) show that groundwater irrigation development is not part of the country's National Development Master Plan.

Groundwater development for irrigation has therefore remained largely the responsibility of small holder farmers in the country. This is done on the basis of local knowledge. Irrigators all over the country draw from this store of knowledge to develop groundwater, irrigate and market their products. For over 200 years, this knowledge has been the driving force behind the spreading of groundwater irrigation from the area between Keta lagoon and the sandbars in southern Ghana to the Atankwidi catchment of the White Volta Basin in the northeast of the country. According to Namara et al. [4], the benefits generated, particularly in the Atankwidi catchment, are the creation of jobs through the demand for labor, and the development of the communities, enhancing the food security status of these farmers, and reducing poverty.

Despite the fact that it has not been given the necessary attention that it deserves, local knowledge has long been recognized globally as a tool for the conservation, protection, development and governance of water resources in general. In Bangladesh, local knowledge enabled local participation in large-scale water management, with local initiatives in water resources management being undertaken by the local people [7]. The Nordic Council of Ministers [8] agreed that local knowledge regarding resources defines local ownership, identity, responsibility, participation and a way of making the rules more locally developed and applicable. Unfortunately replaced with a top-down approach, it is realized that local knowledge enabled local communities to engage in groundwater governance in places such as Rajasthan, for example, through the maintenance of water structures (see Megdal, et al. [9]). In Ghana, Obeng-Odoom [10] eulogized customary water practices immersed in local knowledge which once characterized the country's water sector (Pre-Colonial era) as the best way of governing water resources in the country because they effectively defined water rights, distribution, conservation, and protection mechanisms.

Even in the face of the impacts of climate change on groundwater recharge (5-22\% for 2020 and $30-40 \%$ for 2050 [11]) and records of incidence of fallen groundwater tables already in the northern part of Ghana including Atankwidi [12,13], according to Villholth [14], small holder irrigators in the country drawing from local knowledge have been able to place Ghana among the most promising countries in the continent in terms of groundwater irrigation. In the Upper East Region of the country, it is realized that groundwater irrigators out-number surface water irrigators with the area irrigable with groundwater being greater (see Dittoh et al. [15]).

Despite the important contributions of this knowledge to groundwater development and irrigation, there has not been any in-depth study of it in relation to groundwater development in any part of Ghana to the best of our knowledge. Groundwater studies in the Atankwidi catchment are mostly biophysical with focus on hydrochemistry, hydrogeology, and climate change and recharge (see Pavelic et al. [16]; Obuobie [17]; Martin and van de Giesen [18]). Even when local knowledge is given a place in water resources studies, it is only mentioned and not discussed in detail (see Barry et al. [5]; van den Berg [19]). On the other hand, where attention is given to the study of local knowledge in Atankwidi, this often has to do with other livelihood and environmental activities (see [20]). Other studies relating to local knowledge in the country as a whole are concerned with surface water, vegetation conservation and management practices, general agriculture (soils), biodiversity and forestry among others (see Kwoyiga and Apusigah, [21]; Mikkelsen and Langohr, [22]) and omitted groundwater development.

This article intends to add to the literature by providing information about the long practice of applying local knowledge to develop groundwater for irrigation. It offers a different perspective to understanding groundwater development in the Atankwidi catchment by moving away from geospatial and geophysical techniques and findings which characterize the existing studies in the catchment. This study intends to re-echo the fact that groundwater development has long been immersed in local knowledge and this knowledge is still boosting irrigators' resilience to global change and its impacts on groundwater resources. 
In this article, we outline the ways in which local knowledge enables irrigators to understand and exploit groundwater resources for irrigation. We further identify how this knowledge enables irrigators to cope with insufficient groundwater resources. We argue that local knowledge guides farmers to use environmental indicators such as plants to locate groundwater sites, construct wells and protect the quality of water in them as well as conjunctively use groundwater and surface water during irrigation to cope with insufficient groundwater.

\subsection{Local Knowledge and Water Resources}

The term local knowledge is used sometimes as a synonym for traditional ecological knowledge, indigenous knowledge, native science, traditional environmental knowledge, and adaptive management $([23,24])$. This article equates local knowledge to all these types of knowledge.

Local knowledge according to Berkes et al. [25] (p. 1252) is "holistic in outlook and adaptive by nature, gathered over generations by observers whose lives depended on this information and its use". The authors of [22] (p. 8) note that this knowledge is "a cumulative body of knowledge, practice, and belief, evolving by adaptive processes handed down through generations by cultural transmission, about the relationships of living beings (including humans) with one another and with their environment". This knowledge is pegged to people's experiences and interactions with others and transmitted through stories, apprenticeship, and practices, with this knowledge being fluid, adaptable, and updated with time as new observations and experiences are gathered [26]. In his study in Central Africa, Eyong [9] (p. 122) defines it as "the set of interactions between the economic, ecological, political, and social, environments within a group or groups with a strong identity, drawing existence from local resources through patterned behaviors that are transmitted from generation to generations to cope with change. These patterns are sustained by micro level institutional arrangements vested with differentiated responsibilities that ensure the group's continuous survival".

Local knowledge has, therefore, served as a tool for the development and sometimes for the management/governance of water resources for various human activities including irrigation all over the world, as noted already. In recent times, this is seen with the Integrated Water Management Resource approach where local stakeholders such as community leaders are encouraged to participate in water management decisions based on their accumulation of water-related knowledge over time. Drawing from the River Basin Management approach to managing water resources in Ghana, traditional leaders, such as chiefs and local experts, form part of River Basin Boards. At the community or village level, this knowledge enables communities endowed with water resources to take charge of them locally. This is reflected in the people's understanding and interpretation of these resources. This knowledge, in some instances, fundamentally connects local people super-naturally to these resources. For instance, it is widely believed in Ghana and some African countries that water resources are sacred, with spiritual connotations and should be treated carefully. Thus, through traditional leadership, local people take up the responsibility of protecting and governing these resources.

Of the Marakwets in the Kerio Valley in Kenya, Cheserek [27] discussed how village leaders and heads of clans apply local knowledge to manage water under harsh environmental conditions. Drawing examples from Yemen, Al-Qubatee et al. [28] revealed that local knowledge enables local people to determine the quality of groundwater in their community. As if that is not enough, the Borana and Konso communities in Ethiopia for over five (5) centuries have applied local knowledge to exploit groundwater as they are able to identify suitable well and pond sites [29]. In their study to determine whether groundwater levels could be reliably estimated by oral reporting from traditional wells in the absence of hydrological groundwater monitoring in Zimbabwe, Chikodzi et al. [30] brought to the fore that people such as wells diggers and groundwater diviners possess a good amount of information on local groundwater fluctuation. In a similar vein, Shemsanga [31] recently documented that local knowledge enables the exploitation of groundwater and guides the allocation of different water uses based on qualitative parameters in the Dodoma city in Tanzania. 
In Ghana, the application of local knowledge, particularly to explore and exploit groundwater, remains relevant, especially in some rural communities in the northern part of the country. In Pungu, near Navrongo in the Upper East Region, where dry season irrigation is believed to have originated from, one still finds the construction and use of these wells for dry season irrigation even with the presence of the Tono Irrigation Dam and other community water reservoirs.

Though Sillitoe [32] lamented that until recently, local knowledge was regarded as inefficient, and its application damaging to the environment, and considered outmoded, with the presence of western science and technology challenging its potency and existence, it is evident that this knowledge has been applied to develop, manage and govern water resources. It is therefore not surprising that local knowledge of local communities or indigenous people is gradually gaining momentum in World Water Fora and other international discourses and debates.

\subsection{Groundwater Irrigation in Ghana}

Ghana has groundwater resources [13]. In the northern part of the country, the distribution of these resources according to Gyau-Boakye and Dapaah-Siakwan [33], occurred in two main geologic provinces: basement rocks (54\%) and consolidated sedimentary rocks (45\%). Figure 1 indicates the potentials of groundwater in this part of the country. From Figure 1, it can be said that Atankwidi catchment falls within the zone of moderate groundwater potentials.

Considering its importance, Kortatsi [34] noted that groundwater supports domestic, irrigational and industrial activities in the country. Nonetheless, in the Atankwidi catchment, Martin [12] stated that a larger proportion of groundwater constitutes domestic water supply while about $4 \%$ of it meets irrigational water needs.

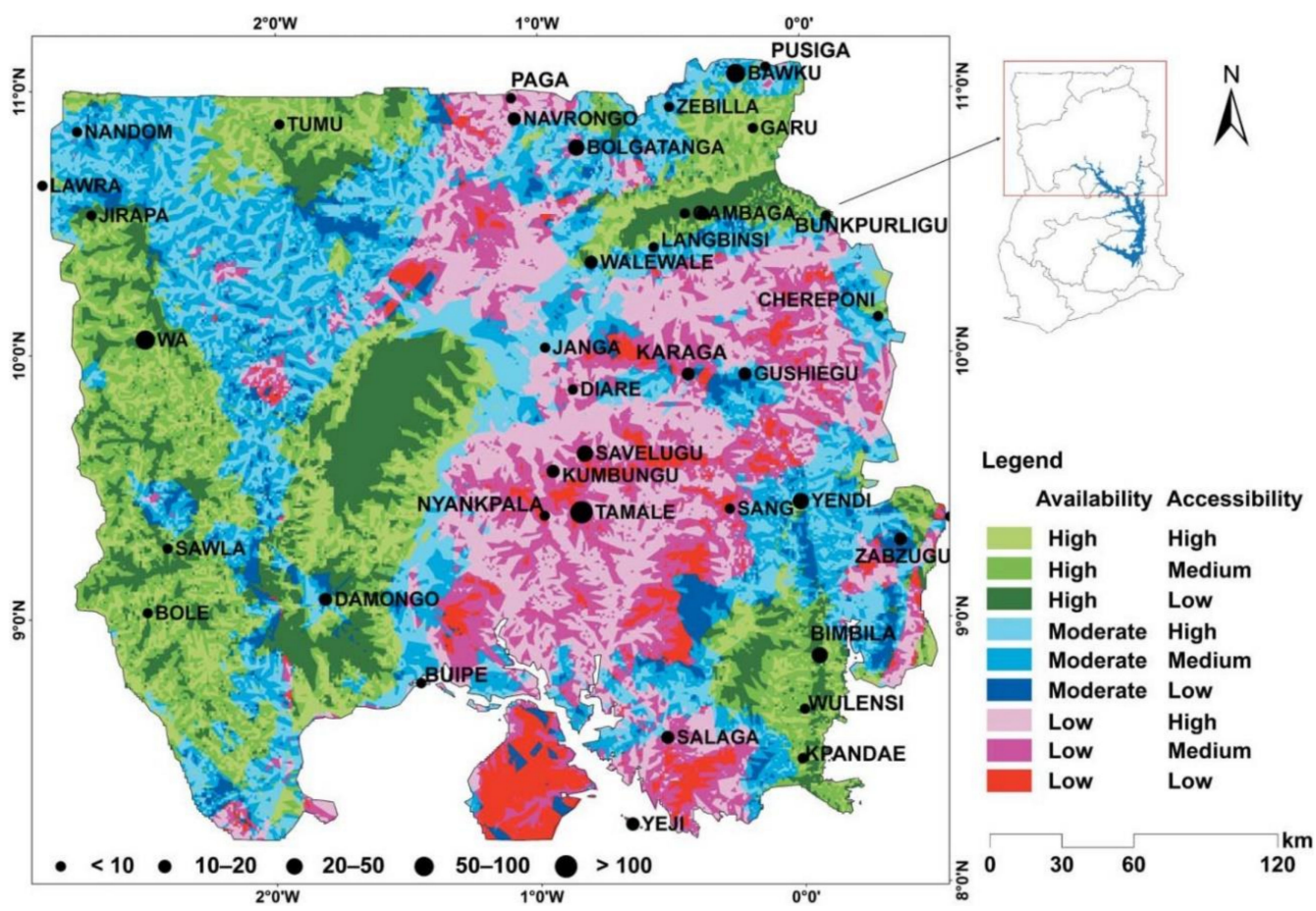

Figure 1. Groundwater development potential map of northern Ghana. Source: Copied from Forkour et al. [35].

Focusing on the nature of groundwater irrigation, Villhoth [14] discussed how the situation in Africa is best understood when viewed through the lenses of the depth of the groundwater utilized and the funding sources. This puts Ghana as a country at a place where groundwater for irrigation is largely a private funding activity with groundwater usually tapped from shallow aquifers or alluvial fans, 
as is the cases in the Upper East and Volta Regions. In the Accra plains of the Greater Accra Region also, boreholes have been constructed for irrigation purposes. Water from these wells is being used to irrigate moderate-to-high salt-tolerant vegetables such as cabbage, onion, tomatoes and carrot [34].

Within the domain of policies and other formal documentations in Ghana, the Ministry of Food and Agriculture (MOFA), and the Ghana Irrigation Development Authority (GIDA) [3], categorize groundwater irrigation as informal: farmers cultivate areas which are at least 0.5 ha, rely on simple structures and equipment, capital investment being small with the source of funding being farmers themselves. Government support for this activity so far in the country according to Chokkakula and Giordano [6] has occurred through the supply of pumps, and the undertaking of some experimental projects of groundwater use with institutions such as the World Bank on a short-term basis.

The GIDA, the agency representing the country's Ministry of Food and Agriculture, has decentralized units in all the regions of the country. Groundwater irrigation is supposed to form part of the activities of this agency; unfortunately, during the fieldtrip in Ghana in 2017, interviews were not granted by the Upper East Regional Director because he claimed that the GIDA is only concerned with surface water irrigation hence has no knowledge of what pertains to groundwater irrigation in the region.

A review of the existing stakeholders and agencies in groundwater irrigation in the country (see MOFA and GIDA [3]) shows the existence of the MOFA, the Water Resources Commission (WRC), Environmental Protection Agency (EPA), and the Centre for Scientific and Industrial Research (CSIR). Nonetheless, there are no traditional authorities or local knowledge holders among them. The responsibilities of these institutions or stakeholders include policy formulation, research and regulation. The WRC has designed a Groundwater Resources Management Strategy which is yet to be implemented. Thus, the truer picture of the existing situation, as far as groundwater irrigation in Ghana is concerned, is that traditional leaders together with local irrigators champion every activity relating to it. Traditional institutions, like norms, taboos and beliefs, are some regulatory structures at the forefront of governance particularly at the catchment level. Unfortunately, population pressure, foreign religions, science and technology, education and some emerging (market) policies relating to land and water are threatening the effectiveness of these institutions.

\section{Materials and Methods}

\subsection{Study Area}

Using a qualitative approach, the Atankwidi catchment was made a case for this study. This is because the people depend almost entirely on groundwater for their livelihood. The catchment is also noted for groundwater irrigation in the dry season. Characteristically, it is transboundary as seen in Figure 2 and a tributary of the White Volta Basin. It has an area of about $286 \mathrm{~km}^{2}$. The Ghanaian part of the basin which is downstream is about $159 \mathrm{~km}^{2}$ [36].

Administratively, it is located in the Upper East Region covering the four districts of Kasena/Nankana Municipality, Kasena/Nankana East, Bolgatanga and Bongo. The catchment covers six (6) villages in Ghana: Kandiga, Sirigu, Yuwa, Zorkpo, parts of Sumbrugu and Mirigu. It has a population of 45,841 in 2010 with $47 \%$ males and $53 \%$ females with the population growth rate being $1.1 \%$ per annum [37]. The settlement patterns are largely rural with only $10 \%$ being urban.

Hydro-geologically, the catchment is characterized by three (3) basement aquifers: shallow perched aquifer, principal regolith and fractured aquifer [12]. According to Martin [12], the regolith aquifer constitutes the principal aquifer in the weathered mantle resulting in a continuous aquifer whose average saturated thickness is $25 \mathrm{~m}$ and supplies the yield of most boreholes (domestic water). The discontinuous shallow perched aquifer is characterized by coarse soils of $0.5 \mathrm{~m}$ to $1.5 \mathrm{~m}$ thickness and covered by a less permeable clayey or lateritic layer. Nonetheless, this aquifer provides water to traditional wells at very shallow depth. Thus, the shallow aquifer is often the source of water for dry season irrigation [19]. 


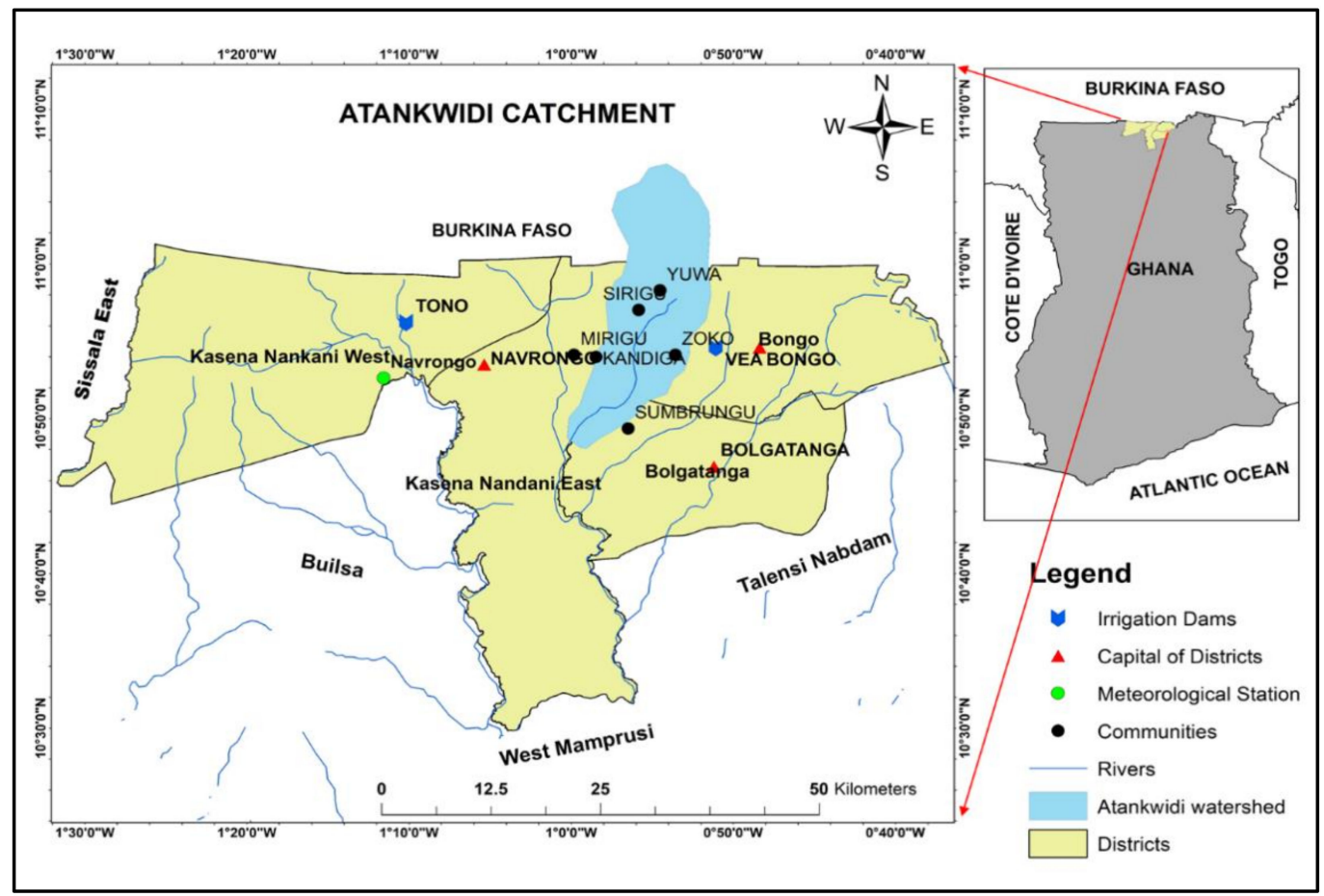

Figure 2. Atankwidi catchment.

Groundwater recharge is between 1 and 13\% of the mean annual rainfall [12]. An assessment of groundwater suitability for irrigation in the Atankwidi catchment was carried out by Barnie et al. [38] based on salinity, sodium, magnesium hazards, $\mathrm{pH}$ and alkalinity. The results show that groundwater is suitable for irrigational activities even though there are potential magnesium hazards and alkalinity challenges.

The total area irrigable by groundwater irrigation according to Barry et al. [5] is about 387 ha. It is noted that there are potentials to expand groundwater irrigation as groundwater abstraction are still within sustainable limits although some existing studies offer contrary views, citing the presence of fallen water tables.

Details about the communities and localities of the Atankwidi catchment where the data were obtained are shown in Table 1. It is important to state that not all localities in the various communities engage in dry season irrigation. Therefore, the localities displayed in Table 1 are some of those that engage in this practice, hence investigated.

Table 1. Population statistics of Atankwidi.

\begin{tabular}{cccccc}
\hline Community & Population & $\begin{array}{c}\text { Number of } \\
\text { Localities }\end{array}$ & Study Locality & $\begin{array}{c}\text { Population of } \\
\text { Locality }\end{array}$ & $\begin{array}{c}\text { Number of Groundwater } \\
\text { Farmers of Study Locality }\end{array}$ \\
\hline Kandiga & 4547 & 6 & Atibabisi & 431 & 133 \\
Mirigu & 4979 & 6 & Nyongo & 859 & 100 \\
Sirigu & 2962 & 8 & Busongo & 128 & 55 \\
Sumbrugu & 14026 & 31 & Kologo Nayire & 547 & 200 \\
Yua & 1069 & 5 & Atarabisi & 625 & 90 \\
Zorkor & 13274 & 12 & Tarongo & 1457 & 15 \\
Total & 40857 & 68 & 6 & 4047 & 593 \\
\hline
\end{tabular}

\subsection{Data for the Study}

Empirical data were generated through a four-month field trip in Ghana in 2017. Two main categories of empirical data were generated. Firstly, irrigators who mostly double up as well drillers were contacted in order to obtain data about the source of land for irrigation, how to identify sites/places with groundwater, the process and time of digging of wells, groundwater quantity 
levels in wells, the maintenance of wells and the protection of groundwater quality. Respondents who were available and willing to participate were selected on a voluntary basis.

Key informants were interviewed to get an insight into the interpretation of the natural environment of which groundwater forms part, the appropriation of land for irrigation, the religious and social dimensions of groundwater resources as well as the geographic/political boundaries of groundwater resources. These included chiefs, elders, earth priests and assembly members from each community. Each community has a chief and an earth priest. Interviews with chiefs were conducted at the chiefs' palaces while those with earth priests were conducted at the homes of these priests.

An interpreter who doubled up as a research assistant provided support during the interviews. This is because the first author, who collected the data, though from northern Ghana, does not speak Frafra or Guruni (the languages spoken by the people of the study communities). The responses in the results sections are thus interpretations.

The data collection tools employed were interviews, observation, conversation and informal discussions.

Group interviews were used to interact with irrigators. This was because the time of the data collection coincided with the rainy season (as activities of dry season irrigation were over) which made it difficult to locate individual irrigators on their vegetable farms. All irrigators also engage in rainy season farming and could only be available for interviews in groups in the afternoon and evening. It was the intention of the researchers to interview 15 men and 15 women in each community; it was, however, realized during the interviews that female participation in groundwater irrigation is low, particularly in some communities. Information about the interviews and their settings is shown in Table 2 below.

Table 2. Composition of respondents and interview settings.

\begin{tabular}{cccc}
\hline Community & Number of Men & Number of Women & Location of Interviews \\
\hline Kandiga & 15 & 15 & Village Square \\
Mirigu & 15 & 15 & Under trees \\
Sirigu & 15 & 0 & Village square \\
Sumbrungu & 15 & 0 & Near community borehole \\
Yua & 14 & 1 & Community Centre \\
Zorkpo & 15 & 0 & Under trees \\
Total & 89 & 31 & \\
\hline
\end{tabular}

The number of female respondents in the data collection was largely influenced by the degree of their engagement in irrigation and their availability at the time of the interviews. The geographic location, land availability and the ease with which groundwater resources are accessed are some major determinants of female participation in irrigation. In Sumbrungu, Kandiga and Mirigu, women are more engaged in irrigation because groundwater is easily tapped from shallow grounds or river beds which require less energy to extract. However, places such as Zorkpo are rocky with groundwater being difficult to exploit through the construction of wells which is usually manual. Unfortunately, though women engage in dry season farming in Sumbrungu, it was not possible to interview them because they were engaged in funeral activities.

Data were first recorded, transcribed and then analyzed manually.

\section{Results}

\subsection{Groundwater Resources and Dry Season Groundwater Irrigation in Atankwidi}

Groundwater resources in Atankwidi are considered a sacred resource in the catchment. The boundaries of this resource here correspond with the boundaries of the land of the local people in the catchment. Communal ownership of resources precedes any other property regime. The commons here are the people of Atankwidi and the history or ancestral lineage of the people define the rights 
of the commons. A traditional political system, comprising chiefs, heads of clans, family heads, and earth priests (lords of the land), exercises authority over the people and groundwater resources. Thus, access and appropriation of groundwater resources, just like land, follow three tiers: the community level; the clan level, and the family level.

Groundwater irrigation is predominantly a male activity as shown in Table 2, but men are sometimes assisted by their wives and other females. Irrigators are mostly the commons which guarantees them automatic access to land and groundwater. However, there are instances where people from nearby communities show interest in irrigation. In such instances, those people access land and groundwater through a lease. Such people are not charged any fees for participation apart from the conditions of the lease, which sometimes involves sharing irrigation products with the lessor. There is no formula for sharing the benefits; however, the lessee uses his discretion. This practice does not constitute any form of payment for using the land/groundwater but just shows appreciation. Items such as cola, tobacco and local drink may accompany the products presented during consultations for the land. In recent times, due to population pressure coupled with limited groundwater, the trend of land acquisition has changed. One now sees the marketization of land creeping in where payment is made as part of the conditions of the lease.

Irrigation is initiated by individual irrigators solely on the basis of local knowledge. This knowledge does not only enable irrigators to interpret and exploit groundwater from shallow aquifers but also for farming (extension, agronomy and even marketing).

Irrigators also support each other in terms of labor during wells' construction, farm security, farm inputs, new improved methods and techniques of farming, marketing and in conflict resolution. Irrigators rely on the proceeds from rainy season farming and support from friends and family members to finance farming activities.

The sizes of the farms vary, as do the water needs of crops. Wells are therefore dug in the field or in the riverine to tap groundwater. The depth of riverine wells is shallower than infield wells. However, most of the wells that are being used are shallow. Each crop field may depend on water from 2-3 wells depending on its size. The riverine wells which are very shallow and temporary are refilled after the dry season to make way for rainy season farming and to also avoid accidents by animals and humans. Water from such wells is usually lifted with the help of a pumping machine. Some infield wells are permanent with farmers providing security for such wells throughout the year.

Irrigators use buckets, ropes, motorized pumping machines, and other simple tools to lift water depending on the water source, financial capacity of farmers, the distance between crops and water sources and available manual labor. The crops grown are usually vegetables such as tomatoes, pepper, carrots, cabbage, onions, egg plants, spinach okra and other local vegetables consumed by them. Some of the products are consumed at home but a larger portion is sold. Marketing of the products is purely organized by farmers themselves through their leaders. Products are either packaged on farms and sold to market women from southern Ghana or put in basins or sacks and sold at the nearest market places such as Sirigu, Navrongo, and Bolgatanga.

Groundwater irrigation is governed by taboos, beliefs, rules and norms. Abstraction of groundwater is based on the construction and maintenance of individual wells. Security for wells is provided by farmers themselves. Irrigators have leaders who facilitate the creation of markets for their products. Depending on the nature of conflicts, leaders of irrigators, earth priests and chiefs intervene. Information about irrigation is mostly shared among irrigators.

\subsection{Indigenous Knowledge for Groundwater Development for Irrigation}

\subsubsection{Nature of Local Knowledge}

Extensive analysis of the interviews and discussions shows that chiefs, elders, irrigators, men and women possess a wealth of local knowledge about the natural environment including groundwater. This knowledge is deeply rooted in the communities and draws from their cultural, economic, natural, 
social and spiritual environment and influences the processes of groundwater exploitation and use for irrigation as shown in Figure 3. For example, religious/spiritual practices usher in the period of irrigation and guide in explorations.

This knowledge forms part of institutions created to regulate the exploitation and use of groundwater without causing harm to the resources in the environment. Institutions in the form of taboos place value on some areas and frown upon groundwater extraction at such sites. It is a taboo to dig wells in places considered sacred (groves) as these places are considered the abodes of their gods/ancestors. In some communities, it is a taboo to draw water from wells in the dead of night.

This knowledge is traced to their first ancestors and accumulated over time through observation, experiences and participation. It is not documented but passes on generationally through oral tradition. Atankwidi catchment is a traditional community of which the majority is rural. Thus, social organizations and interactions are still more closely knitted and this enables the easy diffusion of the knowledge.

It has also emerged that this knowledge of groundwater emanates from multiple sources as evident in Figure 3. Nonetheless, a bulk of it comes from within. However, it is noted that this knowledge comes from other irrigators in neighboring communities such as Pungu and the media such as the radio.

Regarding the primary source of this knowledge within the community, it is realized that it originates from the family (nuclear and extended), particularly male adults. This statement is confirmed by the composition of the respondents in the methods' section where, in communities such as Zorkpo and Yua, only men are involved in irrigation.

With contacts from outside the communities as mentioned already, irrigators have observed that the existing knowledge is diffused by other knowledge, thus it is refined with time. Nonetheless, socialization plays a fundamental role in the acquisition of this knowledge, particularly among men in their formative years. Regarding this knowledge, the following are excerpts of the interview responses.

A farmer in the Kandiga interview group said:

My knowledge about groundwater resource comes from my forebears. I learned from my father and grandfather about the presence of water beneath the surface of the ground. In those days in the dry season, whenever we were faced with inadequate surface water, I supported my father to dig a well. Our friends and relatives supported us also in the process. People from my compound also assisted other community members to dig their wells. Digging a well in those days was usually on our own family lands either closer to the compound or away from the house. Wells have been a major source of water for us in this community, particularly in the dry season.

A farmer in the Mirigu interview group added:

I first acquired knowledge about groundwater resources from my father and my uncles. You know we live in compound houses and every older person takes part in nurturing you into an adult. We were taught and participated in every life activity including how to dig wells particularly at the beginning of the dry season for drinking, livestock use and for farming. My father and uncles had vegetable gardens. My knowledge about wells and vegetable farming began to deepen when I turned a teenager. Mirigu is not far from Pungu (Navrongo) and there are a lot of these wells also for vegetable farming in that area. I got to know of these activities outside Mirigu when we used to walk from Mirigu through Pungu to Navrongo market in those days as bicycles motorbikes, and vehicles were not common.

\subsubsection{Aspects of Local Knowledge for Exploring and Exploiting Groundwater for Irrigation}

One of the aims of this paper is to assess the ways in which Local knowledge enables irrigators to understand, explore and develop groundwater for irrigation in the dry season. The results show that 
this knowledge guides irrigators to locate groundwater sites, know the source and time of groundwater recharge, construct wells, among other tasks, as presented in the ensuing discussion.

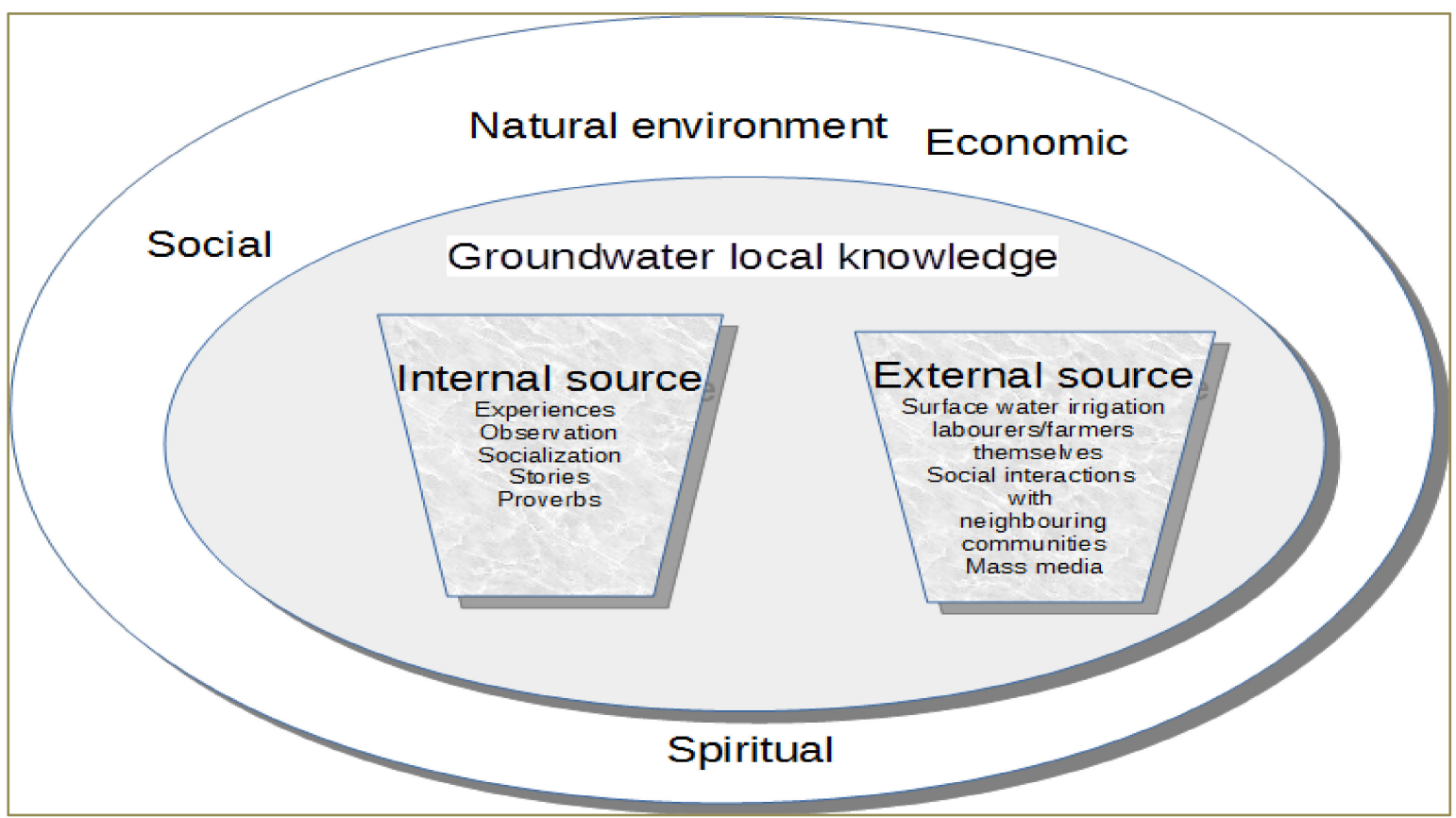

Figure 3. Composition of local knowledge.

Location of Groundwater Sites

It is realized that irrigators do not have any modern technology, instruments or equipment that enable them to study the hydrogeology of groundwater resources. However, there exist some environmental indicators as shown in Figure 4 that guide them in the process of locating places to dig wells. For instance, the presence of shrubs, broom plants, trees such as the Ficus gnaphalocarpa, thorns/thorn grasses, black ants, old wells, and nearby water bodies indicate groundwater availability. It is realized that most of the respondents, especially irrigators, are familiar with where to dig for water. This is because most of the irrigators double up as well drillers.

A respondent in Mirigu interviewed group noted:

I know where to dig and get water. You see Figus gnaphalocarpa trees, not only are the fruits edible but their roots also indicate groundwater availability. Look, in this community, it is common to find wells near places where this tree is located. This tree is so important that we don't just cut it down like that.

\section{Groundwater (Wells) Quality Protection and Pollution Control Mechanism}

As noted already, irrigators cultivate vegetables. This, therefore, requires the use of water that is of good quality; thus, wells, particularly infield permanent wells, are protected. Protection is, however, a challenge for riverine wells since they are usually shallow with wide openings. Regarding the infield wells, their mouths are fenced with short walls using building materials. This is to make them safer to stand and draw water and also to cover. The covers are made from local materials such as wood, straw or metal roofing sheets. The use of the covers thus prevents waste from being blown into the wells and the straying of animals and humans inside the wells. The immediate surroundings of these wells are often kept tidy. Some irrigators consciously manually dredge their wells, especially when they suspect that there is an accumulation of waste, mud and other pollutants in the water. This aims at improving the quality of the water.

A farmer in Zorkpo interview group said: 
We drink and use the water from our infield wells to cook. Nobody goes home when farming starts. Our homesteads are far and there are no boreholes around so we tidy up the surrounding of these wells and also protect the water from pollution.

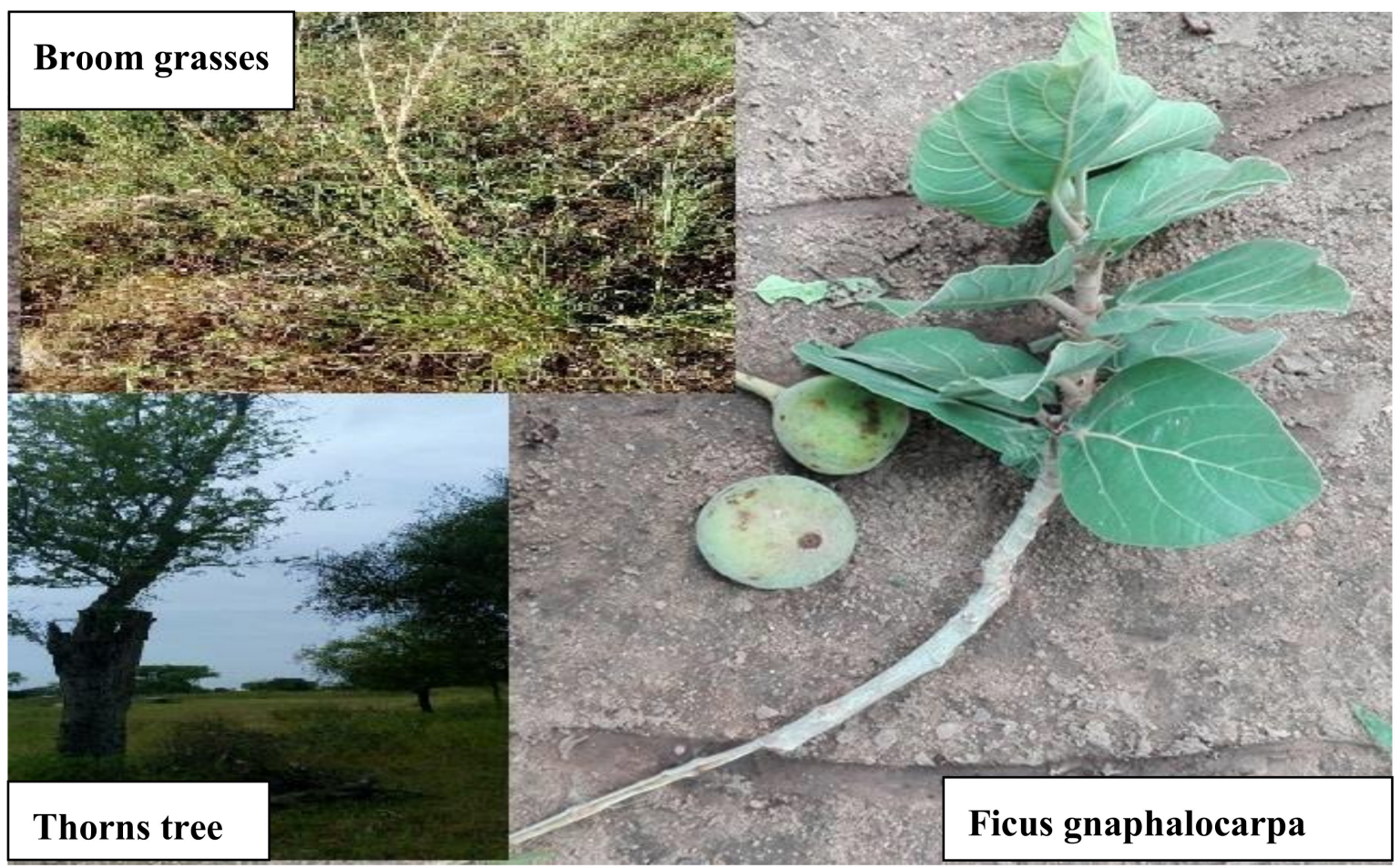

Figure 4. Groundwater indicators in Atankwidi.

Source and Time of Recharge

Irrigators know that groundwater in the catchment is recharged largely through rainfall. They explained this as the sipping down of rainwater through the pores of the soil, a process they claim is gradual and takes several days, months and even years. The respondents further explained that even though they cannot quantify the volume of rain water which constitutes groundwater, they can categorically say that rainfall amount and intensity are proportional to groundwater recharge. The number of respondents with this knowledge about groundwater recharge is, however, low, as mostly older men (35-50 years) who had gained experience over time appear to have this knowledge.

A respondent in Yua interview group said:

We have rainy and dry seasons. We only see water when it rains, so we all know that apart from the water running into our rivers, part of it goes beneath the ground surface. That is why it is common to see bubbles discharging water in our wells in the rainy season.

We hardly see this in the dry season.

Period for Constructing Well

The northern part of Ghana is characterized by two seasons: the rainy (wet) and dry season. Groundwater irrigation is done in the dry season. According to the respondents, there is a specific month from which wells can be dug. Wells are often dug at the end of the rainy season: from the month of October. This is because, when the ground is dry, it is easier to avert wells construction-related disasters as there are instances where, in the process of digging, some wells cave in or collapse on them. This situation is often common when the moisture content of the soil is high.

A farmer in Sumbrungu interview group said: 
Who does not fear death? We have records of our colleagues dying due to the collapse of wells on top of them. We have noted that the ground is usually wet before October; we learnt to wait until the soil moisture reduces before we start digging.

Additionally, activities in the rainy season may not permit them to construct such wells at any other time apart from the dry season because land for dry season farming is also used for rainy season farming. Rainy season activities usually come to an end by September. Irrigators, in order to avoid clashes with their seasonal activities and for safety reasons, start to dig wells from October.

\section{Wells Construction and Development}

The results show that simple tools such as calabashes, dibbers, ropes, buckets and of late axes are used during construction. The diameter or opening of the infield wells at the initial stage is usually small but increases with depth until a desirable diameter is attained. Respondents have explained that buckets and ropes are used to lift the soil from the wells to the outer surface as the digging progresses. Shallow wells are mostly dug by farmers themselves in this season as no special skill is required. These are easier to dig and may take hours or fewer days. Infield wells are sometimes dug with the assistance of well drillers even though some of the irrigators are able to do so themselves.

A farmer in Kandiga interview group said:

Digging wells is not easy but we have to do it in order to tap water for irrigation. So, sometimes as the depth especially of infield increases, we tie ropes round our waist when descending the wells to dig: this is to help us return to the surface in case of an emergency like threats of well collapse. We also make sure the walls of these wells are not susceptible to erosion.

Some irrigators who own infield or permanent wells use stones, boulders and other materials such as cement to line these wells. This, according to irrigators, improves the quality of the water by preventing erosion on the walls of the wells, and increases the life span of their wells.

\subsubsection{Local Knowledge for Adaptation to Limited Groundwater}

As the article sets out to further address the ways by which local knowledge enables irrigators to adapt to limited groundwater situation, it can be deduced from the interviews that different options exist with multiple responses/choices given by the irrigators. Factors such as age, land tenure system, geographic location, income, education and the nature of the activity (full/part-time) influence farmers' choices of the adaptive strategies. For instance, irrigators who own land themselves tend to invest more in digging, maintaining and deepening them. Additionally, farmers who are about 50 years of age are less willing to migrate to other places in search of groundwater. Moreover, those who have the financial capacity invest more on access to multiple sources of water such as buying pumping machines to tap water from shallow grounds while depending, at the same time, on an infield well.

\section{Number of Wells per Crop Area}

According to the respondents, in recent times, groundwater is not in abundance even though the depths of wells are deeper than before. The recordings of high temperatures cause high evaporation of well water and increase soil moisture deficit. In order to meet the ever-increasing water demand, irrigators are compelled to dig at least two wells depending on the water needs of the crops on that portion of land. This is common with riverine farmers who dig shallow dug outs which easily dry up, thus more such wells are required. Such farmers also have pumping machines which support in lifting water from wells. 


\section{Continuous Deepening of Wells' Depth}

Another strategy that irrigators have adopted to cope with the limited groundwater situation is to increase the depth of their wells frequently. This is to enable farmers to have more access to groundwater which is usually at its lowest level at the peak of the dry season. With the help of family members, friends and sometimes hired labor, some owners of infield wells further increase the depth of their wells. This activity sometimes takes at least a day.

\section{Conjunctive Use of Surface and Groundwater}

Further, local knowledge enables irrigators to identify ways and means of reducing pressure on available groundwater by delaying its use during cropping. This is to ensure that enough groundwater is stored and made available for use when needed. Irrigators, particularly those located along the riverine conjunctively use surface water from rivers and streams nearby with groundwater. With the help of pumping machines, treadle pumps and other water transport devices, irrigators lift water from these places to irrigate their crops. This normally happens at the early stage of planting. This reduces the pressure exerted on the groundwater wells and diversifies the sources of water for these crops. By the time these water bodies dry up, the crops would have taken in enough water already. Farmers then continue to irrigate with groundwater from wells. This has enabled farmers to cope with the scarcity of groundwater available for their crops.

\section{Nursing of Seedlings in the Rainy Season}

Closely linked to the use of surface water is the issue of farmers nursing seedlings using other sources of water besides groundwater. Farmers in the catchment, based on experience and local knowledge, have realized that with the scarcity of groundwater that they often face, it is prudent to use rain water to nurse their seedlings. As a result, during the rainy season, from the month of July, most farmers start to nurse their seedlings. These seedlings enjoy sufficient water from the rain and are ready for transplant onto the crop fields from October when the dry season farming starts. This has become a common practice of dry season farmers. Farmers who are not able to nurse their own seedlings during the rainy season prefer to buy these seedlings from other farmers rather than using groundwater for this purpose. This is because such farmers feel that the cost of buying these seedlings is less than the cost involved in using groundwater for this purpose.

\section{Efficient Irrigation Groundwater Application}

To adjust to the challenges of limited groundwater availability, irrigators have learnt to efficiently apply water to their crops in a less wasteful manner. Water is applied directly to the roots of crops using watering cans, buckets, calabashes and tubes. Irrigators have time tables that inform them of when to water their crops. Watering of crops is not every day. Drawing and lifting water manually is tedious. Additionally, the distance between the source of water and the crop area is sometimes long. In order to save water, time and energy, irrigators tend to apply water judiciously to the roots of crops. Hence, water application is done with a high degree of efficiency to prevent losses/waste and only on days that crops need water.

\section{Change in Crop Types}

Over the years, farmers have realized that in order to stay productive, there is a need to search for alternative crops that match with the available groundwater supply. Irrigators have, therefore, begun to adopt crops that depend less on water. It is noted that crops such as tomatoes are cultivated; however, farmers are beginning to plant crops such as legumes. This is to ensure that farmers still earn a living through farming. Even though this option appears to be a solution to the groundwater problems faced by the irrigators, it is not considered the best option. This is because irrigators think 
that vegetable crops earn them more income than the latter and meet their immediate household food needs. Irrigators in Mirigu are beginning to adopt this option.

Migrate to Other Groundwater Resources-Endowed Areas

Groundwater conditions elsewhere influence farmers' choice of coping with limited groundwater conditions at their current locations. Some farmers therefore migrate to places considered to be less stressed in term of availability. Though this is the least favored option of irrigators, it is now a yearly routine of farmers in Yua. Yua, by geographical location, is in proximity to southern Burkina Faso. As noted already, the catchment is transboundary with shallow groundwater irrigation familiar with both Ghanaian and Burkinabe farmers. Farmers from Yua, therefore, migrate to Burkina Faso (areas near the border) where it is believed there is available groundwater with easy access. Irrigators in Yua admitted that their counterparts in Burkina Faso are supported to secure water by the government. This entices Yua farmers to migrate to these places in Burkina Faso with the hope of enjoying some of these water conditions.

\section{Discussion}

This article addresses an important component of irrigation in Africa: local knowledge as a tool for developing water resources. The findings of this study show that the exploration and exploitation of groundwater for irrigation in the Atankwidi catchment of Ghana is only possible through the sole application of local knowledge.

Before proceeding, it must be stated that the use of group interviews has yielded sufficient responses even though individual interviews were initially preferred. Errors in the responses of some respondents during the interview process were immediately corrected by others. Interviewers were able to contact irrigators even when the dry season irrigation was over. The voluntary participation and willingness of irrigators further enhanced the quality of the data. This is because local knowledge is a special knowledge which is not generally distributed. This saved time and resources of interviewing people who were less knowledgeable. Nonetheless, the interviewers had to make sure that some individuals did not hijack or dominate during the interviews.

\subsection{Local Knowledge and Groundwater Development}

The findings show the value of local knowledge for groundwater development. This knowledge guides irrigators to identify groundwater points using environmental indicators such as plants/vegetation. A confirmation of these as groundwater indicators is by Meinzer [39] in his work Plants as Indicators of Groundwater. Drawing from his findings, plant species such as Acacia horrida (sweet thorn), ebony and tamarisk trees are indicators of groundwater at shallow depth. The tussock grass which the people of Atankwidi referred to as broom grass according to Meinzer [39] is a common groundwater plant which indicates groundwater at a depth to the water table of about 10 to 15 feet. In a similar vein, the World Bank [26] stated that trees such as Daniella Olivieri are indicators of groundwater in the Northern Region of Ghana.

On the part of local knowledge and groundwater recharge, it is realized that the findings of recharge correspond with the analysis of groundwater recharge levels given by Martin [12]. In her study, she indicated that recharge of groundwater in Atankwidi catchment occurs after several intense showers of rain in the middle of the rainy season. Regarding the source and time of recharge of groundwater, the findings match again with analysis of groundwater recharge levels by Martin [12] where it is shown that recharge is largely from rainfall and occurs in the middle of the rainy season. The application of local knowledge is, however, limited here. It is realized that local knowledge regarding groundwater recharge is strictly explained as a function of rainfall only, unlike scientific methods which also recognize artificial recharge processes such as Managed Aquifer Recharge to boost recharge. 
Based on experiences of soil characteristics, the results confirmed that places that are characterized by sandy soils experience faster recharge than clayey areas; this has been noted already by Martin [12] of the catchment where soils with high clay content are seen to have low hydraulic conductivity and associated with water logging.

The findings again from the study show that measures have been put in place to protect the quality of water in wells from pollution. Some of these practices are similar to the guidelines adopted by the Community Water and Sanitation Agency (CWSA) of Ghana of borehole facilities for providing domestic water supply. That is, human activities within a 50 meters radius are prohibited in the case of groundwater, with the siting of latrines supposed to be at the downstream of water sources. However, it is realized that apart from preventing direct pollution of water from environmental and human activities, local knowledge is unable to allow for the study of the natural chemical constituents of groundwater for irrigation.

Unfortunately, local knowledge does not permit owners of wells in both categories to exhibit any sense of consciousness/feelings for aquifer protection (to avoid depletion). As a pool, groundwater is extracted based on the capabilities of irrigators without considering the sustainable yields of these aquifers. The only restraining factor about wells' allocation is the use of taboos where farmers are forbidden from digging wells in places considered sacred (groves). This has implications for sustainability.

\subsection{Local Knowledge for Adaptation to Limited Groundwater}

Regarding the ways and means of coping with groundwater insufficiency, the findings show that local knowledge enables irrigators to be strategic. Guided by this knowledge, irrigators make choices depending on their capabilities and other prevailing conditions. For instance, some prefer to deepen the depths of existing wells while others increase their number per crop area or adopt both.

Some of these strategies in the catchment have been noted also by van den Berg [15] who says that irrigators need about $2-3$ wells on small fields and 3-5 wells on large fields, while some have to reopen old wells in order to have sufficient water for their crops.

It is realized that the irrigation efficiency of water is about 70\% ([35]). Water is applied directly to the roots of crops using watering cans, buckets, calabashes and tubes. The conjunctive use of both surface and groundwater resources is one of the stipulations of modern-day groundwater legislation [36], because of the merit of easing pressure on a particular source of water. This is, however, an expensive measure for irrigators because of the cost involved in acquiring pumping machines and sometimes fueling them.

Apart from these, irrigators have also decided to nurse seedlings in the rainy season by taking advantage of rain water. This is seen to be cost effective as seedlings are naturally nursed with ease. Some irrigators are even able to earn income from this through the sale of their surplus seedlings to irrigators who are unable to nurse seedlings in the dry season. Some irrigators are also beginning to adopt different varieties of crops such as legumes that need less water compared to the existing ones. However, this option appears less rewarding to irrigators compared to the cultivation of vegetables.

Viewing this knowledge within the context of governance, it is realized that traditional leaders guided by norms, taboos and beliefs, govern groundwater resources. It can thus be said that this knowledge goes beyond just the construction and maintenance of wells for irrigation. There is the sharing of responsibilities from the level of the individual irrigator to the group (all irrigators in the catchment). Information is also shared among irrigators. One sees the collective but largely independent actions of local irrigators together with their traditional leaders a manifestation of groundwater governance as stated by Foster and Garduño [40], even though the aspects of groundwater sustainability and protection need attention in this era of global change. As Shah [41] (p:205) stated, "groundwater governance worldwide is a work in progress". The situation in Atankwidi, on the basis of local knowledge for irrigation, can be likened to this. 
This study is significant because it shows that the people of Atankwidi have some understanding of their groundwater resources: usually regarded as invisible and difficult to study or interpret. It shows that apart from science and technology, local communities drawing from their knowledge are conversant; they can interpret and independently explore their resources to some level. This study has therefore delineated what is already known and done by the local community. This understanding offers some basis for local support of any external intervention in the development and governance of groundwater in the catchment once there is local participation. It shows that local knowledge can complement scientific knowledge for addressing water issues at the catchment level in developing countries such as Ghana

\section{Conclusions}

The place of local knowledge for understanding and developing groundwater for dry season irrigation, which is seldom discussed in research studies in Ghana, is presented in this article. Irrigators are able to use indicators such as trees to not only identify groundwater points, but also identify the source of recharge.

Irrigators draw from this knowledge to cope with the insufficient water situation by increasing the number of wells per crop area, deepen the depth of wells or conjunctively use groundwater with alternative water. It is evident that this knowledge still remains relevant in the catchment. Though groundwater irrigation is poorly covered in government policy documents, irrigators show resilience in seeking and accumulating this knowledge from both within and outside the catchment to develop groundwater for irrigational purposes.

However, this knowledge does not contribute to any artificial groundwater recharge or ways of augmenting groundwater availability. With climate change/impacts and population growth besieging the catchment, groundwater may be negatively affected and this may affect dry season irrigation.

It can thus be said that effective collaboration between local irrigators and the formal government will enhance the usefulness of local knowledge. That is, recognizing, documenting and integrating this knowledge into mainstream irrigational strategies/measures in the country. It is, however, recommended that groundwater irrigation in the country's irrigation policies should be comprehensive and action oriented. Efforts in this regard may provide better water development and management options which are less expensive, simple, sustainable, and more acceptable.

Author Contributions: Conceptualization; Data curation; Formal analysis; Funding acquisition; Methodology and Writing—original draft were by L.K.; while Resources, Supervision; Writing—review and editing, were done by C.S.

Funding: The research received funding from DAAD and the Graduate Academy, TU Dresden for the doctoral studies / field work in Ghana.

Acknowledgments: The authors acknowledge the contributions of Professor Paul Alagidede through informal discussions to the article. The INOWAS Junior Research Group, TU Dresden is also acknowledged for support in terms of literature/materials for the article.

Conflicts of Interest: The authors declare that there is no conflicting interest.

\section{References}

1. National Research Council. Prospects for Managed Underground Storage of Recoverable Water; The National Academies Press: Washington, DC, USA, 2008.

2. Foster, S.; Tuinhof, A.; Van Steenbergen, F. Managed groundwater development for water-supply security in sub-Saharan Africa: Investment priorities. Water SA 2012, 38, 359-366. [CrossRef]

3. Ministry of Food and Agriculture National Irrigation Policy, Strategies and Regulartory Measures; Ministry of Food and Agriculture, Ghana Irrigation Development Authority: Accra, Ghana, 2011.

4. Namara, R.E.; Horowitz, L.; Nyamadi, B.; Barry, B. Irrigation Development in Ghana: Past Experiences, Emerging Opportunities, and Future Directions; GSSP Working Papers; International Food Policy Research Institute: Accra, Ghana, 2011. 
5. Barry, B.; Kortatsi, B.; Forkuor, G.; Gumma, M.K.; Namara, R.E.; Rebelo, L.-M.; van den Berg, J.; Laube, W. Shallow Groundwater in the Atankwidi Catchment of the White Volta Basin: Current Status and Future Sustainability; International Water Management Institute (IWMI): Colombo, Sri Lanka, 2010; Volume 139.

6. Chokkakula, S.; Giordano, M. Do policy and institutional factors explain the low levels of smallholder groundwater use in Sub-Saharan Africa? Water Int. 2013, 36, 790-808. [CrossRef]

7. Chadwick, M.; Soussan, J.; Mallick, D.; Alam, S. Understanding Indigenous Knowledge: Its Role and Potential in Water Resource Management in Bangladesh; University of Leeds and Bangladesh Centre for Advanced Studies: Leeds, UK; Dhaka, Bangladesh, 1998.

8. Nordic Council of Ministers and Nordic Council of Ministers Secretariat. Local Knowledge and Resource Management: On the Use of Indigenous and Local Knowledge to Document and Manage Natural Resources in the Arctic; Nordic Council of Ministers: Copenhagen, Denmark, 2015.

9. Megdal, S.B.; Eden, S.; Shamir, E. Water governance, stakeholder engagement, and sustainable water resources management. Water 2017, 9, 190. [CrossRef]

10. Obeng-Odoom, F. Marketising the commons in Africa: The case of Ghana. Rev. Soc. Econ. 2016, 74, 390-419. [CrossRef]

11. Kankam-Yeboah, K.; Obuobie, E.; Amisigo, B. Climate Change Impacts on Water Resources in Ghana; Ghana National Commission for UNESCO: Accra, Ghana, 2009; pp. 65-69.

12. Martin, N. Development of a water balance for the Atankwidi catchment, West Africa: A case study of groundwater recharge in a semi-arid climate. Ph.D. Thesis, University of Goettingen, Goettingen, Germany, 2006.

13. Johnston, R.M.; McCartney, M. Inventory of Water Storage Types in the Blue Nile and Volta River Basins; International Water Management Institute (IWMI): Colombo, Sri Lanka, 2010; Volume 140.

14. Villholth, K.G. Groundwater irrigation for smallholders in Sub-Saharan Africa-A synthesis of current knowledge to guide sustainable outcomes. Water Int. 2013, 38, 369-391. [CrossRef]

15. Dittoh, S.; Awuni, J.A.; Akuriba, M.A. Small pumps and the poor: A field survey in the Upper East Region of Ghana. Water Int. 2013, 38, 449-464. [CrossRef]

16. Pavelic, P.; Villholth, K.G.; Shu, Y.; Rebelo, L.-M.; Smakhtin, V. Smallholder groundwater irrigation in Sub-Saharan Africa: Country-level estimates of development potential. Water Int. 2013, 38, 392-407. [CrossRef]

17. Obuobie, E. Estimation of groundwater recharge in the context of future climate change in the White Volta River Basin, West Africa. Ph.D. Thesis, Rheinischen Friedrich-Wilhelms-Universität Bonn, Bonn, Germany, November 2008.

18. Martin, N.; Giesen, N. van de Spatial Distribution of Groundwater Production and Development Potential in the Volta River basin of Ghana and Burkina Faso. Water Int. 2005, 30, 239-249. [CrossRef]

19. Van den Berg, J. Exploring Shallow Groundwater Irrigation: Current Status and Future Application. A Case Study in the Atankwidi Catchment, Ghana. Master's Thesis, Delft University of Technology, Delft, The Netherlands, June 2008.

20. Derbile, E.K. Local Knowledge and Livelihood Sustainability under Environmental Change in Northern Ghana. Ph.D. Thesis, Rheinischen Friedrich-Wilhelms-Universität zu Bonn, Bonn, Germany, October 2010.

21. Kwoyiga, L.; Apusigah, A.A. Community-Based Ecotourism for Sustainable Development in Ghana. In Ecotourism and Sustainable Tourism: Management, Opportunities and Challenges; Richard, P.H., Ed.; Nova Publishers: New York, NY, USA, 2017; pp. 85-113.

22. Mikkelsen, J.H.; Langohr, R. Indigenous knowledge about soils and a sustainable crop production, a case study from the Guinea Woodland Savannah (Northern Region, Ghana). Geogr. Tidsskr. Dan. J. Geogr. 2004, 104, 13-26. [CrossRef]

23. Whyte, K.P. On the role of traditional ecological knowledge as a collaborative concept: A philosophical study. Ecol. Process. 2013, 2, 7. [CrossRef]

24. McNamara, K.E.; McNamara, J.P. Using participatory action research to share knowledge of the local environment and climate change: case study of Erub Island, Torres Strait. Aust. J. Indig. Educ. 2011, 40, 30-39. [CrossRef]

25. Berkes, F.; Colding, J.; Folke, C. Rediscovery of traditional ecological knowledge as adaptive management. Ecol. Appl. 2000, 10, 1251-1262. [CrossRef] 
26. Pearce, T.; Ford, J.; Willox, A.C.; Smit, B. Inuit traditional ecological knowledge (TEK), subsistence hunting and adaptation to climate change in the Canadian Arctic. Arctic 2015, 68, 233-245. [CrossRef]

27. Cheserek, G. Indigenous Knowledge in Water and Watershed Management: "Marakwet" Conservation Strategies and Techniques. FWU Water Resour. Publ. 2005, 3, 25-33.

28. Al-Qubatee, W.; Ritzema, H.; Al-Weshali, A.; van Steenbergen, F.; Hellegers, P.J. Participatory rural appraisal to assess groundwater resources in Al-Mujaylis, Tihama Coastal Plain, Yemen. Water Int. 2017, 42, 810-830. [CrossRef]

29. Behailu, B.M.; Pietilä, P.E.; Katko, T.S. Indigenous practices of water management for sustainable services: Case of Borana and Konso, Ethiopia. SAGE Open 2016, 6. [CrossRef]

30. Chikodzi, D.; Murwendo, T.; Simba, F.M. Reliability of indigenous knowledge in monitoring and mapping groundwater fluctuations in Zimbabwe. Int. J. Dev. Sustain. 2014, 3, 231-241.

31. Shemsanga, C.; Muzuka, A.N.N.; Martz, L.; Komakech, H.; Mcharo, E. Indigenous knowledge on development and management of shallow dug wells of Dodoma Municipality in Tanzania. Appl. Water Sci. 2018, 8, 59. [CrossRef]

32. Sillitoe, P. Let them eat cake: Indigenous knowledge, science and the 'poorest of the poor'. Anthr. Today 2000, 16, 3-7. [CrossRef]

33. Gyau-Boakye, P.; Dapaah-Siakwan, S. Groundwater as source of rural water supply in Ghana. J. Appl. Sci. Tech. 2000, 5, 77-86.

34. Kortatsi, B. Groundwater utilization in Ghana. IAHS Publications-Series of Proceedings and Reports-Intern. Assoc. Hydrol. Sci. 1994, 222, 149-156.

35. Forkuor, G.; Pavelic, P.; Asare, E.; Obuobie, E. Modelling potential areas of groundwater development for agriculture in northern Ghana using GIS/RS. Hydrol. Sci. J. 2013, 58, 437-451. [CrossRef]

36. Salifu, T.; Agyare, W.A. Distinguishing different land use types using surface albedo and normalized difference vegetation index derived from the SEBAL for the Atankwidi and a farm sub catchments in Ghana. J. Eng. Appl. Sci 2012, 7, 69-80.

37. Ghana Statistical Service 2010 Population and Housing Census: Summary Report of Final Results; GSS, Government of Ghana: Accra, Ghana, 2012.

38. Barnie, S.; Anornu, G.; Kortatsi, B. Assessment of the Quality of Shallow Groundwater for Irrigation in the Atankwidi Sub-Basin of the White Volta Basin, Ghana. J. Nat. Sci. Res. 2014, 4, 1-11.

39. Meinzer, O.E. Plants as Indicators of Ground Water; Water Supply Paper; U. S. Government Printing Office: Washington, DC, USA, 1927; 95p.

40. Foster, S.; Garduño, H. Groundwater-resource governance: Are governments and stakeholders responding to the challenge? Hydrogeol. J. 2013, 21, 317-320. [CrossRef]

41. Shah, T. Climate change and groundwater: India's opportunities for mitigation and adaptation. Environ. Res. Lett. 2009, 4, 035005. [CrossRef]

(C) 2018 by the authors. Licensee MDPI, Basel, Switzerland. This article is an open access article distributed under the terms and conditions of the Creative Commons Attribution (CC BY) license (http:/ / creativecommons.org/licenses/by/4.0/). 